\title{
Biased Decision-Making and Liquidity Buffer in Commercial Banking
}

\author{
Mingyuan Sun \\ Correspondence: Mingyuan Sun, Graduate School of Economics, Kyushu University, Fukuoka, Japan. \\ Received: November 13, 2017 \\ doi:10.11114/aef.v5i2.2784 \\ Accepted: January 12, 2018 Available online: January 28, 2018 \\ URL: https://doi.org/10.11114/aef.v5i2.2784
}

\begin{abstract}
Few derived versions based on the classic bank run model have taken into account the framing effect of general lenders. The purpose of this study is to revisit the issue and discuss a model of bank run equilibrium combined with biased risk preference, which is applied to analyze how portfolio allocation and liquidity buffer in commercial banks are affected by liquidation cost and the reference point. The results suggest the condition on which the liquidity buffer of a particular bank should provide. Liquidation cost is positively correlated with the lower bound of liquidity buffer. The effect of the reference point on liquidity buffer partially depends on the slope of yield curve term structure. Higher reference point could typically cause a lower portion of long-term investment.
\end{abstract}

Keywords: liquidity, reference point, liquidation, lower bound, bank run

JEL Classification: G11, G21, G40

\section{Introduction}

Financial innovation has changed the traditional definition of liquidity provision and also altered the risk structure of the banking system amid the boom since 1990s and the burst in the recent financial crisis. Liquidity risk within a financial institution has been inherent for several years even if new business model constantly emerges. However, liquidity shock from liabilities side is relatively unpredictable. Aside from traditional bank run, stop rolling over in the wholesale funding takes a form of "silent run" during the recent credit crunch. The recent crisis shows how quickly the liquidity of an asset can evaporate even if a few signals indicate the crisis coming prior to the crisis. New regulation standards have been established along with the Basel III which was enacted in 2010. One of the important reforms is the Liquidity Coverage Ratio which is introduced to monitor liquidity risk and ameliorate the short-term resilience to liquidity shocks of banking institutions. The core of concern is to make sure the banks have liquidity buffer to meet the liquidity needs within a specified time span.

How the framing effect in the decision-making of lenders affect portfolio allocation and liquidity buffer have not been fully studied despite of the progressive development of the epic Prospect Theory (Kahneman and Tversky, 1979). The obscure risk characteristics embedded in particular asset categories such as mortgage-related securities that played a significant role in the financial crisis have critical effects on the stability of both individual banks and the whole banking system.

In both academia and industry, the focus has been partially changed from credit risk to liquidity risk, but the importance of liquidity risk is still underemphasized. Based on the classic model of Diamond and Dybvig (1983), this study applies the concept of reference point in the Prospect Theory to make a further understanding of portfolio allocation and liquidity buffer in commercial banking, which helps to uncover of the natural vulnerability and present policy implications.

The remainder of this paper is organized as follows. Section 2 presents the literature review. Section 3 specifies the theoretical model and the conditions of bank run equilibrium. Section 4 presents the empirical evidence and section 5 concludes this study.

\section{Literature Review}

Along the main storyline of early literature on bank run equilibrium, Diamond and Dybvig (1983) proposed a that a self-fulfilling bank run is an equilibrium in the classic model. This model is future developed by several researchers. Cooper and Ross (1998) incorporated deposit insurance into the model and analyzed the strategy of holding excess reserves to deal with the allocation. Ennis and Keister (2009a) discussed the intervention policy efficiency in the face of system-wide bank runs and the incentives of depositors. In another framework, Ennis and Keister (2010) argued that banks will be overly optimistic about the needs of depositors and do not have sufficient resources to deal with the needs. 
While Allen and Gale (1998) disagreed with the view that banking crisis is a version of self-fulfilling prophecy and argued that bank runs are affected by fundamental economic fluctuations in business cycles. With the constraint of sequential service, depositors have the concern that others withdrawing before them will be served better and paid more, thus they have the incentive to participate in a bank run. Green and Lin (2003) used a finite-trader framework to show that ex ante efficient allocation can be implemented even if there are sequential service constraints, which implies that an efficient arrangement of allocation can be made without any bank runs under the mechanism they specified. However, Ennis and Keister (2009b) responded to this argument that the possibility of self-fulfilling bank run cannot be ruled out by changing only one assumption. Goldstein and Pauzner (2005) proposed a model in which the probability of bank runs could be measured and constructed a deposit contract that can make a balance between the benefits of liquidity provision and the cost of bank runs. In the recent crisis, liquidity risk stems from exposure to undrawn loan commitments, withdrawals of funds of wholesale deposits and losses of other short-term financing, rather than the claim of demand deposits, the difference of wholesale funding risk from traditional detail funding risk characterized in later studies. Uhlig (2010) provided a model in which bank runs are typically driven by institutional withdrawals instead of general depositors and discussed the motives of outside investors who will be potential buyers of the securities the distressed banks need to sell. In most of the existing frameworks, relative risk-aversion utility is usually employed, however they did not pay much attention to the psychological framing effect, especially the risk preference features proposed in the Prospect Theory (Kahneman and Tversky, 1979), in which people make decisions depending on how it is presented and what effect it will bring to the bank run equilibrium.

Holmström and Tirole (1997) discussed the moral hazard issue in financial intermediaries and documented that banks will have little incentive to monitor the lending if the net assets decline. Morris and Shin (2004) presented that liquidity black hole of a risky asset will emerge when short-sighted investors trade homogeneously. Diamond and Rajan (2000) argued that equity capital can act as a buffer to protect depositors. Likewise, there are some implications drawn from non-traditional banking businesses. Berger and Bouwman (2009) concluded that commercial banks create over half of their liquidity through off-balance sheet activities. Kashyap et al (2002) argued that synergy exists between deposits and loan commitments and both services require banks to hold balances of liquid assets to provide liquidity on demand. It is also shown that banks which have more illiquid assets tend to reduce lending and negatively affect the overall credit supply (Cornett, McNutt, Strahan, \& Tehranian, 2011). Loutskina (2010) discussed the role of securitization in bank liquidity and the effect on funding management, and argued that the banks are holding less liquid assets than before because of the development of securitization.

Insufficient information about the exposure positions the banks held against subprime assets lead to weakening confidence of investors and a large-scale withdrawal occurred despite some of the banks were far from insolvency. Brunnermeier and Pedersen (2009) argued that liquidity in financial system can be classified into two categories: finding liquidity and market liquidity. Brunnermiere (2009) also discussed equity funding and debt with longer maturities and concluded that leveraged investors will be forced to unwind their positions when funding liquidity problems occurred. Deposit funding pressure was widespread and particularly exacerbated in the first phase of the crisis from the asset-backed commercial paper market (Acharya, Schnabl, \& Suarez, 2013). A concept concluded by Acharya and Moya (2015) emphasizes that the recent crisis is mainly caused by the collapse of liquidity provider mechanism of banks. However, few researches analyze the impact on internal liquidity of banks on the perspective of mortgage-related securities and the corresponding decision-making when they are under severe liquidity pressure.

\section{Theoretical Framework}

\subsection{The Environment}

The purpose of this research is to revisit the classic bank-run equilibrium by employing the reference point which is one important anchoring effect from psychological feature of the Prospect Theory. In the theoretical setting, I follow the classic framework of bank run equilibrium originally developed by Diamond and Dibvig (1983) and further studied in several following literature. The original theory analyzes banks' traditional business model with maturity mismatch and suggests that banks are subject to a natural vulnerability and the equilibrium of a self-fulfilling bank-run exists. Retail and wholesale funding are also included in the setting.

Suppose there are three periods 0,1 and 2 . At period 0 , a depository institution has the total endowment of D units as deposits from both retail and wholesale depositors. Suppose there are $n_{r}$ retail depositors and $n_{w}$ wholesale depositors who are holding $D_{r}$ units and $D_{w}$ units of deposits respectively. The depository institution has two ways to allocate the endowment, which are storage and investment as the same terminology in the classic model setting. If 1 unit of cash is allocated into storage, the depository institution will have the payoff of $r$ in period 1 and $r^{2}$ in period 2 if compounded. If the unit of cash is allocated into investment, it will receive $R$ in period 2 and $R(1-\tau)$ when it is withdrawn prematurely in period 1 , where $\tau \in[0,1]$ is the liquidation cost.. The depository institution will make a decision on what proportion of 
endowment will be allocated into investment, which is denoted by $i$ and the fraction (1-i) is allocated into storage. The storage and investment can be regarded as liquid assets and illiquid assets respectively.

Both retail and wholesale depositors have inter-temporal choices to make use of their accounts. Retail depositors can choose to withdraw the funds in their accounts in either period 1 or period 2. Correspondingly, the depository institution will provide the depositors with $\mathrm{C}_{\mathrm{E}}$ in period 1 and $\mathrm{C}_{\mathrm{L}}$ in period 2. Assume that the proportion of depositors who will choose to withdraw in period 1 is deterministic, and these depositors are "impatient depositors" as opposed to "patient depositors" who will wait to withdraw till period 2 . The proportion of early withdrawal is denoted by $\pi \in[0,1]$. On the other hand, wholesale lenders take a different form of withdrawal by not rolling over their funding en masse into the next term. The proportion of the wholesale funding which is not rolled over is denoted by $\omega$. There is another assumption that the probability of not rolling over is $\eta$.

Retail depositors as homogenous agents have a utility function based on the goods they will consume at each period. The consumption depends upon the cash the depository institution is able to provide. The utility function will take the form of $\mathrm{U}(\mathrm{c})$, where $\mathrm{c}$ is the consumption. For the purpose of mathematical tractability, a specific closed-form utility function is specified in this setting. The major feature different from previous literature is that the utility function is strictly concave and increasing only if the independent variable is over certain threshold. It is more realistic in the model of bank run. The utility of depositors will be negative instead of zero if the payment they receive is less than the threshold because of the framing effect. So the utility will turn into zero when consumption reaches some threshold, and this threshold is at most the legitimate claim of the depositor.

$$
\mathrm{U}(\mathrm{c})=\frac{(\alpha+\beta \mathrm{c})^{1-\varphi}}{1-\varphi}
$$

Where $\alpha<0$ and $\beta>0$, which implies that the original curve makes a rightward shift along the $\mathrm{c}$ axis and the distance it moves is $(-\alpha / \beta)$. The distance is the threshold and $(\alpha / \beta) \in[-1,0)$ is here defined as threshold coefficient. $\varphi \in(0,1)$ is a positive coefficient related to risk preference of depositors. Decreasing risk aversions imply that the agent will increase the risky asset investment if his or her wealth is increased.

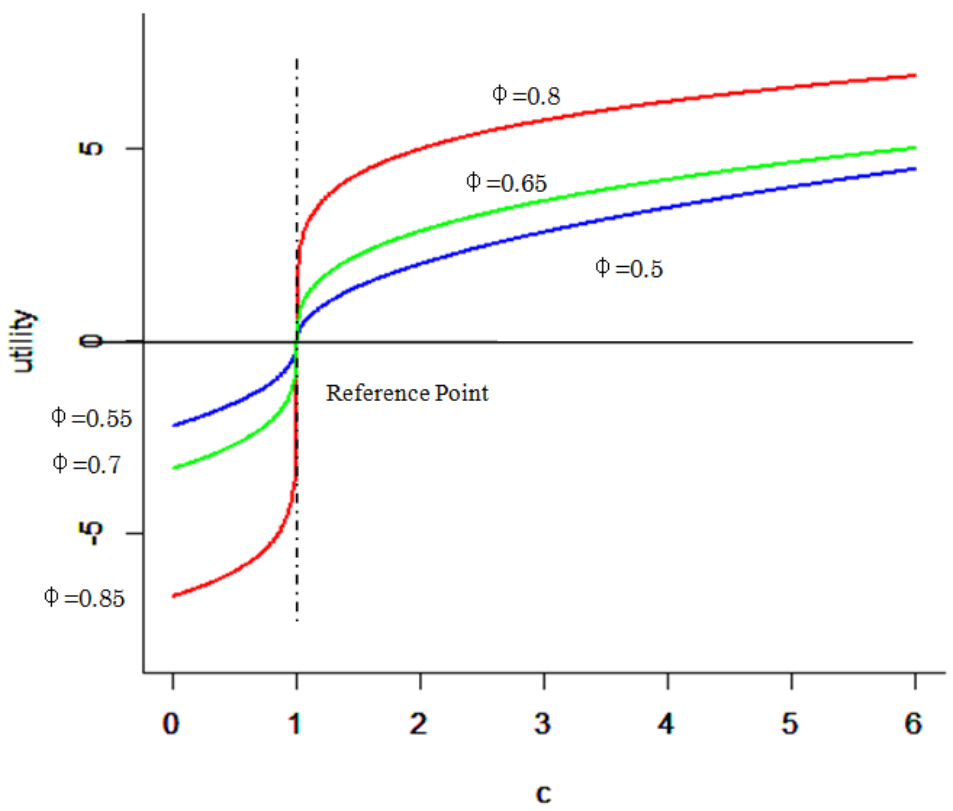

Figure 1. Utility Function with Reference Point

The figure above indicates typical utility curves under the setting above. With different coefficient $\varphi$ and threshold coefficient $=-1$, the concavity of the curve only exists when the consumption is over the threshold. This simplified closed-form utility function is an approximation to the framing effect emphasized in the Prospect Theory created by Kahneman and Tversky (1979) and further developed in 1992, in which it is argued that the "pain" in the losses is greater than the "joy" in the same amount of gains. The threshold in the utility function can be considered as the reference point.

\subsection{The Bank Run Equilibrium}

The strategy for the depository institution is to find the optimal equilibrium in the face of the inter-temporal demands. The maximization problem follows the classic setting that a bank will have the following maximization problem: 
There are several conditions to which the maximization will be subject. The first intuition is that the bank should provide patient and impatient depositors with available funds according to respective demand. In the setting of this study, liquidity buffer is introduced to be provided for the contingent demand from wholesale funding. LB and LB ${ }^{\epsilon}$ represent the liquidity buffer held by the institution at time $t=1$ and $t=2$ and they can be cash reserves or liquid assets. $L B^{\epsilon}$ is he expected liquidity buffer that is the residual liquid assets remaining in the balance sheet after the bank meets the contingent demands of wholesale lenders. The contingent demands could be characterized by the expected wholesale funding withdrawal $\mathrm{W}_{1}$ at $\mathrm{t}=1$, which is specified by

$$
\mathrm{E}\left(\mathrm{W}_{1}\right)=\eta \omega \mathrm{D}_{\mathrm{w}}+(1-\eta) \cdot 0
$$

As it is specified in the previous section, $\eta$ is the probability of the event that lenders stop rolling over the funds to the bank. There will be no cash outflow if lenders keep rolling over the funds. The expected amount of wholesale withdrawal at $\mathrm{t}=2$ can be calculated through the following table. If the wholesale lenders stop rolling over their funds, the amount of $\omega \mathrm{D}_{\mathrm{w}}$ will be paid at $\mathrm{t}=1$ and the claim at $\mathrm{t}=2$ will be $(1-\omega) \mathrm{D}_{\mathrm{w}}$. Otherwise, if the wholesale lenders keep rolling over the funds to the second period, the bank will hold the funds till $t=2$ and the whole amount $D_{w}$ will be repaid at the end of the second period.

Table 1. Matrix of Wholesale Funding Demand

\begin{tabular}{lcc}
\hline & not rolling over & rolling over \\
\cline { 2 - 3 } Probability & $\eta$ & $1-\eta$ \\
Wholesale Claim at $\mathrm{t}=2$ & $(1-\omega) \mathrm{D}_{\mathrm{w}}$ & $\mathrm{D}_{\mathrm{w}}$ \\
\hline
\end{tabular}

Therefore, the expected amount of wholesale withdrawal at $\mathrm{t}=2$ will be

$$
E\left(W_{2}\right)=\eta(1-\omega) D_{w}+(1-\eta) D_{w}
$$

Then the expected liquidity buffer $\mathrm{LB}^{\epsilon}$ will be the difference between the expectation of $\mathrm{LB}$ and $\mathrm{E}\left(\mathrm{W}_{2}\right)$. Theoretically, $L^{\epsilon}=\left|E(L B)-E\left(W_{2}\right)\right|=\left|\left(\eta\left(L B-\omega D_{w}\right) r+(1-\eta) L B r\right)-\left(\eta(1-\omega) D_{w}+(1-\eta) D_{w}\right)\right|$. Optimally, the liquidity buffer LB at the first period should be designed to perfectly hedge the contingent funding claim from wholesale lenders, hence there will be the equation $\mathrm{LB}-\omega \mathrm{D}_{\mathrm{w}}=0$ and the expected liquidity buffer $\mathrm{LB}^{\epsilon}$ should be $(1-\eta) \mathrm{LBr}-$ $(1-\eta \omega) D_{w}$.

The amount provided to impatient depositors should be the fraction allocated into storage subtracting liquidity buffer, which is $(1-i) D-L B$. Since $\pi$ is the proportion of early withdrawal, then the amount provided for impatient depositors, which is $\pi \mathrm{n}_{\mathrm{r}} \mathrm{C}_{\mathrm{E}}$, should be equal to $(1-\mathrm{i}) \mathrm{D}-\mathrm{LB}$. For patient depositors, the amount should be equal to the fraction of investment plus the expected liquidity buffer $L^{\epsilon}{ }^{\epsilon}$ in period 2. The wholesale lenders make this special withdrawal by not rolling over their funding in period 2 . The funding amount of not rolling over is $\omega \mathrm{D}_{\mathrm{w}}$

$\max$

subject to

$$
\pi U\left(C_{E}\right)+(1-\pi) U\left(C_{L}\right)
$$

$$
\begin{gathered}
\pi \mathrm{n}_{\mathrm{r}} \mathrm{C}_{\mathrm{E}}=(1-\mathrm{i}) \mathrm{D}-\mathrm{LB} \\
(1-\pi) \mathrm{n}_{\mathrm{r}} \mathrm{C}_{\mathrm{L}}=\mathrm{iDR}+\mathrm{LB}^{\epsilon} \\
\mathrm{LB}^{\epsilon}=(1-\eta) \mathrm{LBr}-(1-\eta \omega) \mathrm{D}_{\mathrm{w}} \\
\eta \omega \mathrm{D}_{\mathrm{w}} \leq \mathrm{LB}, \mathrm{R}>1, r>1, \mathrm{C}_{\mathrm{E}}>-\frac{\alpha}{\beta}, \mathrm{C}_{\mathrm{L}}>-\frac{\alpha}{\beta} \\
0<i<1,0<\pi<1,0<\eta<1,0<\omega<1
\end{gathered}
$$

The first-best allocation can be obtained by solving this nonlinear maximization. By taking partial derivatives of $\mathrm{C}_{\mathrm{E}}$ and $\mathrm{C}_{\mathrm{L}}$ respectively, the closed-form solutions can be made as follows:

$$
C_{E}^{*}=\frac{\frac{\alpha}{\beta}(1-\pi)\left[1-\left(\frac{\mathrm{R}}{\mathrm{r}} \frac{1}{\varphi}\right]+\left(\mathrm{Rd}+\mathrm{lb}^{\epsilon}\right)-\frac{\mathrm{R}}{\mathrm{r}} \mathrm{lb}\right.}{\pi \frac{\mathrm{R}}{\mathrm{r}}+(1-\pi)\left(\frac{\mathrm{R}}{\mathrm{r}}\right)^{\frac{1}{\varphi}}}
$$

and

$$
\mathrm{C}_{\mathrm{L}}^{*}=\frac{\frac{\alpha}{\beta} \pi\left[1-\left(\frac{\mathrm{r}}{\mathrm{R}}\right)^{\frac{1}{\varphi}}\right]+(\mathrm{rd}-\mathrm{lb})+\frac{\mathrm{r}}{\mathrm{R}} \mathrm{lb}}{(1-\pi) \frac{\mathrm{r}}{\mathrm{R}}+\pi\left(\frac{\mathrm{r}}{\mathrm{R}}\right)^{\frac{1}{\varphi}}}
$$

where 


$$
\mathrm{lb}=\frac{\mathrm{LB}}{\mathrm{n}_{\mathrm{r}}}, \mathrm{lb}^{\epsilon}=\frac{\mathrm{LB}^{\epsilon}}{\mathrm{n}_{\mathrm{r}}}, \mathrm{d}=\frac{\mathrm{D}}{\mathrm{n}_{\mathrm{r}}}
$$

The fraction i allocated into investment can be derived based on the results above as well. The equilibrium solutions of $\mathrm{C}_{\mathrm{E}}^{*}$ and $\mathrm{C}_{\mathrm{L}}^{*}$ are to some extent more intricate than the general results through applying utility function with constant relative risk aversion. It is intuitive to see that the payments $\mathrm{C}_{\mathrm{E}}^{*}$ and $\mathrm{C}_{\mathrm{L}}^{*}$ are different from the payments under the assumption of constant relative risk aversion, and this variation of equilibrium will compromise the condition in which a bank run occurs.

\subsection{Liquidation Cost and Risk Preference}

When $\mathrm{n}_{\mathrm{r}} \mathrm{C}_{\mathrm{E}} \leq(1-\mathrm{i}) \mathrm{D}+\mathrm{iDR}(1-\tau)+\mathrm{LB}$, the bank run will not happen in period 1 because the cash flow from both storage and liquidated investment is sufficient to cover the payment $\mathrm{C}_{\mathrm{E}}$. Then the condition takes the form as follows:

$$
\mathrm{C}_{\mathrm{E}}^{*} \leq(1-\mathrm{i}) \mathrm{d}+\mathrm{idR}(1-\tau)+\mathrm{lb}
$$

In addition, another condition has to be satisfied that the payment for an individual depositor who chooses to withdraw in period 2 should be greater than the payment for period 1 because of the time value of funds. Here the second condition is formed to be:

$$
\mathrm{C}_{\mathrm{E}}^{*}<\mathrm{C}_{\mathrm{L}}^{*}
$$

By applying the closed-form solutions in the equilibrium, the condition (2) is equivalently specified as follows:

$$
\mathrm{i} \leq \frac{\Lambda_{1} \mathrm{lb}-\mathrm{lb}^{\epsilon}+\Lambda_{2}}{\Lambda_{3}(1-\mathrm{R}+\mathrm{R} \tau)} \text { when } \tau>\frac{\mathrm{R}-1}{\mathrm{R}}
$$

where

$$
\begin{gathered}
\Lambda_{1}=\frac{\mathrm{R}}{\mathrm{r}}\left[1+(1-\pi)\left(\frac{\mathrm{R}}{\mathrm{r}}\right)^{\frac{1-\varphi}{\varphi}}+\pi\right]>0 \\
\Lambda_{2}=\mathrm{d}\left[(1-\pi)\left(\frac{\mathrm{R}}{\mathrm{r}}\right)^{\frac{1}{\varphi}}+\left(\frac{\mathrm{R}}{\mathrm{r}}\right) \pi\right]-\mathrm{Rd}-\frac{\alpha}{\beta}(1-\pi)\left[1-\left(\frac{\mathrm{R}}{\mathrm{r}}\right)^{\frac{1}{\varphi}}\right] \\
\Lambda_{3}=\mathrm{d}\left[(1-\pi)\left(\frac{\mathrm{R}}{\mathrm{r}}\right)^{\frac{1}{\varphi}}+\left(\frac{\mathrm{R}}{\mathrm{r}}\right) \pi\right]>0
\end{gathered}
$$

As the reference point is employed in the model, it indicates that the possibility of a bank run is not solely dependent on the liquidation cost and the risk preference is another indispensible factor. As $\Lambda_{3}$ is always positive, the upper bound of investment ratio will get lower as the liquidation cost grows.

The risk preference of depositors is typically represented by the reference point (RP in the figure below). When all other variables are considered constant, a rightward move of the reference point would cause the investment ratio i to decline. However, as the utility becomes negative when the consumption is smaller than the reference point, the concavity will be altered.

Numerical instances are more intuitive as it is depicted below. Scenario A shows the classic equilibrium in which a bank run condition would not be triggered. As the reference point moves rightwards, both $\mathrm{C}_{\mathrm{E}}^{*}$ and $\mathrm{C}_{\mathrm{L}}^{*}$ will decrease and the latter will drop even faster due to a bigger rate of descent. When the reference point goes up by 1 unit, the change of $\mathrm{C}_{\mathrm{E}}^{*}$ will be less than 1 unit and $\mathrm{C}_{\mathrm{L}}^{*}$ will directly decrease. 
A

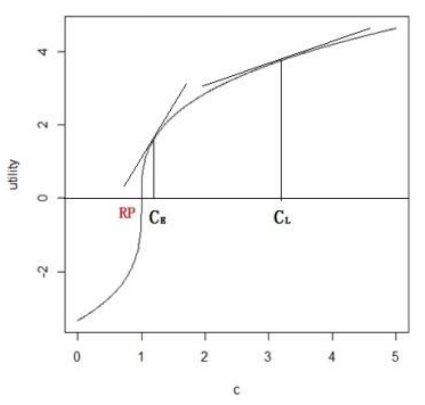

B

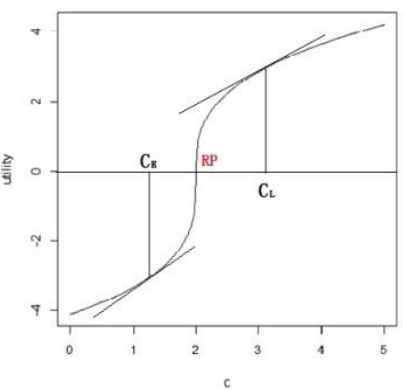

$\mathrm{C}$

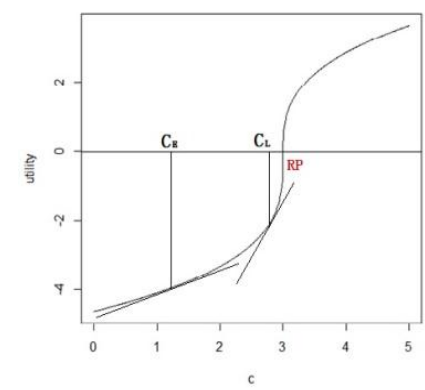

Figure 2. Reference Point and the Equilibrium Solutions

Scenario B and C are also possible status in which both the "impatient" and "patient" depositors will suffer from a negative utility. The condition (2) will not be satisfied eventually if the reference point keeps increasing. It implies that there will be a bank-run equilibrium even if the first condition sustains. In general, the investment ratio i should be negatively correlated with the reference point.

$$
\frac{\partial \mathrm{C}_{\mathrm{E}}^{*}}{\partial\left(-\frac{\alpha}{\beta}\right)}=\frac{(1-\pi)\left(\frac{\mathrm{R}}{\mathrm{r}}\right)^{\frac{1}{\varphi}}-(1-\pi)}{(1-\pi)\left(\frac{\mathrm{R}}{\mathrm{r}}\right)^{\frac{1}{\varphi}}+\pi \frac{\mathrm{R}}{\mathrm{r}}}<1
$$

and

\subsection{Liquidity Buffer}

$$
\frac{\partial \mathrm{C}_{\mathrm{L}}^{*}}{\partial\left(-\frac{\alpha}{\beta}\right)}=\frac{\pi\left[\left(\frac{\mathrm{r}}{\mathrm{R}}\right)^{\frac{1}{\varphi}}-1\right]}{(1-\pi) \frac{\mathrm{r}}{\mathrm{R}}+\pi\left(\frac{\mathrm{r}}{\mathrm{R}}\right)^{\frac{1}{\varphi}}}<0
$$

Liquid assets held by financial institutions as a buffer could function as the "first resort" against contingent liquidity shortage. The transformation of condition (1) and (2) in terms of liquidity buffer is specified as follows:

$$
\begin{aligned}
& \mathrm{lb}+\frac{\mathrm{r}}{\mathrm{R}} \mathrm{lb}^{\epsilon}>d r+\frac{\alpha}{\beta}\left[(1-\pi) \frac{\mathrm{r}}{\mathrm{R}}+\pi\right] \\
& \Lambda_{1} \mathrm{lb}-\mathrm{lb}^{\epsilon} \geq \Lambda_{3}(1-\mathrm{R}+\mathrm{R} \tau) \mathrm{i}-\Lambda_{2}
\end{aligned}
$$

Through the combination of the two conditions above, the condition turns to be:

$$
\begin{aligned}
& \left(\frac{\mathrm{R}}{\mathrm{r}}+\Lambda_{1}\right) \mathrm{lb}>\frac{\alpha}{\beta}\left\{2-\left(\frac{\mathrm{R}}{\mathrm{r}}\right)^{\frac{1}{\varphi}}+\pi\left[\left(\frac{\mathrm{R}}{\mathrm{r}}\right)^{\frac{1}{\varphi}}+\left(\frac{\mathrm{R}}{\mathrm{r}}\right)-2\right]\right\}+ \\
& \mathrm{i} \Lambda_{3}(1-\mathrm{R}+\mathrm{R} \tau)+\mathrm{d}\left[2 \mathrm{R}-(1-\pi)\left(\frac{\mathrm{R}}{\mathrm{r}}\right)^{\frac{1}{\varphi}}-\left(\frac{\mathrm{R}}{\mathrm{r}}\right) \pi\right]
\end{aligned}
$$

First, it is clear that this particular lower bound of liquidity buffer will be raised with a higher liquidation cost $\tau$, which means the ideal position of liquidity buffer should be positively correlated with the liquidation cost. Before the recent financial crisis, assets such as mortgage-related securities with investment-grade ratings were once sufficiently liquid. It did not have to cost too much for investors to liquidate the assets. However, as the model implies, if the liquidation cost suddenly moves upwards due to liquidity shocks, the liquidity buffer should be increased accordingly. The shortage of buffer will lead to liquidity stress.

The reference point affects the liquidity buffer in a more subtle way. To some extent, it depends on the relationship between the proportion of "impatient depositors" and the term structure of the market interest rate. If the following condition is satisfied: 


$$
\pi<\frac{\left(\frac{\mathrm{R}}{\mathrm{r}}\right)^{\frac{1}{\varphi}}-2}{\left(\frac{\mathrm{R}}{\mathrm{r}}\right)^{\frac{1}{\varphi}}+\left(\frac{\mathrm{R}}{\mathrm{r}}\right)-2}
$$

when

$$
\left(\frac{\mathrm{R}}{\mathrm{r}}\right)^{\frac{1}{\varphi}}>2
$$

Then the correlation between the reference point and the liquidity buffer will be positive. The ratio of long-term rate $\mathrm{R}$ to short-term rate $r$ can be obtained by taking the term structure as a proxy, while the coefficient $\varphi$ is difficult to be observed in the real world. In the recent years, prevailing low interest rates flatten the slope of the term structure, making the ratio of $\mathrm{R}$ to $\mathrm{r}$ drop to an extent that condition (8) is reversed. In that situation, the lower bound of the liquidity buffer declines when the reference point moves rightwards regardless of any change of other variables.

\section{Empirical Evidence}

\subsection{Methodology and Data}

The analysis in the previous section could shed some light on how the portfolio structure and liquidity buffer would be affected by the liquidation cost and the reference point. In this section, empirical tests are conducted to find support for the theoretical work. The empirical framework is described in the following linear panel model:

$$
I R_{i, t}^{k}=B_{0, i}^{k}+\beta_{1}^{k} T A U_{i, t-1}+\beta_{5}^{k} G A P_{i, t-1}+\sum \beta_{5}^{k} \text { Controls }_{i, t}+\mu_{i, t}
$$

Where IR means the investment ratio i specified in the theoretical setting, and TAU represents the liquidation cost of a particular asset. Controls are a series of control variables. A perfect proxy variable for the reference point is hard to be acquired straightforwardly. However, a circuitous method can be applied to find an observable indicator, which is denoted by GAP and takes the following form:

$$
G A P=\frac{\text { interest rate }_{L}-\text { interest rate }_{S}}{\text { fundamental rate }}
$$

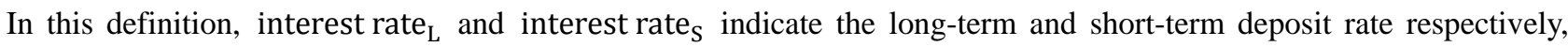
and fundamental rate represents a basic risk-free interest rate in the corresponding quarter. In this study, the average 3-month Treasury bill rate is selected as the basic rate. In theory, the bigger the variable GAP is, the harder for the reference point to get close to $\mathrm{C}_{\mathrm{L}}^{*}$. With the introduction of GAP, the negative correlation between the reference point and IR is converted into an expected positive correlation.

The data in this study is selected from the FFIEC Call Reports. The range is from the first quarter of 2001 to the last quarter of 2016. The whole sample is also divided into three periods: pre-crisis (2001Q1-2007Q2), crisis (2007Q3-2009Q1) and post-crisis (2009Q2-2016Q4).

The interest rate spread between the yield of Mortgage-backed Securities (MBS) and U.S. Treasury securities and U.S. Government agency obligations is calculated for the explanatory variable IR. There are two reasons for choosing MBS in the model portfolio: first, securities are typically the option for liquidation when liquidity shocks occur, and MBS is an important part in this category; second, it also helps to understand the feature of banking liquidity risk for the fact that MBS was involved deeply in the recent financial crisis. Within this asset category of MBS, non-agency MBS market is shrinking to a record and agency MBS nearly dominates the aggregate market after the recent crisis. Agency and non-agency MBS positions in both large and small domestic banks diverged since the onset of the crisis. The empirical analysis is only conducted in the level of aggregate exposure. 

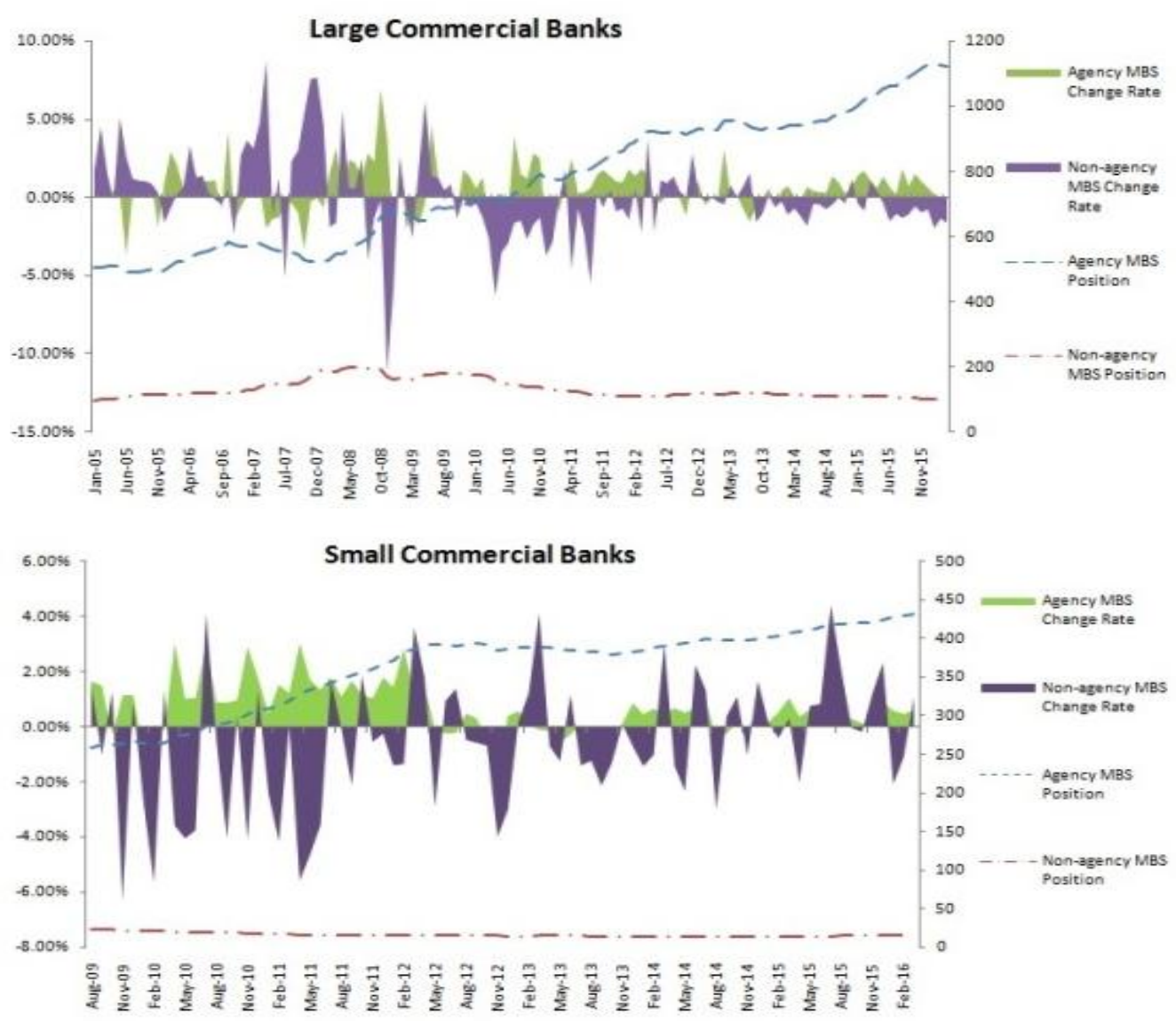

Figure 3. Agency ${ }^{1}$ and Non-agency ${ }^{2}$ MBS Exposures in Large and Small Domestic Banks

Source: Federal Reserve Assets and Liabilities of Commercial Banks in the United States-H8

In the calculation of GAP, the interest rate spread of Savings Deposits, Time Deposits and Time Deposits to Transactions Deposits are selected into the dataset. Control variables consist of profitability (ROA), capital sufficiency (Tier I Risk-based Capital Ratio), liquidity sufficiency (Liquidity Ratio) and potentiality of non-performing loans (Provisions for Loan and Lease Losses standardized by Total Assets) and bank size (Total Assets).

Table 2. Descriptive Statistics

\begin{tabular}{lllll}
\hline Variables & Description & Mean & Median & s.d. \\
\hline$I R$ & Investment Ratio & 0.454 & 0.445 & 0.368 \\
TAU & Liquidation Cost & 0.046 & 0.002 & 7.497 \\
GAP1 & Interest Rate Spread of Deposits & 0.015 & 0.005 & 1.575 \\
GAP2 & Accounts (standardized by T-bill & 0.078 & 0.018 & 1.599 \\
GAP3 & rate) & 0.091 & 0.019 & 2.320 \\
LIQRAT & Liquidity Ratio & 0.094 & 0.071 & 0.081 \\
CAPRAT & Capital Ratio & 0.178 & 0.150 & 0.209 \\
ROA & Returns on Assets & 0.005 & 0.005 & 0.010 \\
$P T L L$ & Provisions for Loans and Leases & 0.005 & 0.001 & 0.629 \\
$T A^{3}$ & Total Assets & 12.026 & 11.865 & 1.346 \\
\hline
\end{tabular}

Source: Calculated by FFIEC Call Reports

\subsection{Empirical Results}

According to the theoretical model, the relationship between the investment ratio and the liquidation cost is negative. The empirical results indicate that a significant linkage does exist in the group of small commercial banks, and the sign of the coefficient TAU is also consistent in large commercial banks in spite of insignificance. This finding is consistent with previous literature even if the model construction is changed with the introduction of liquidity buffer as a variable.

The coefficient of Liquidity Ratio is more significant in large banks than that in small banks. Banks with higher Capital Ratio tend to have a higher investment ratio i, especially in the subsample of small banks, but institutions with better ROA typically have a lower proportion of mortgage-backed securities. Size effect represented by total assets shows 
banks with bigger size will make more investment into MBS, although the size effect is already controlled by separating large banks from small banks.

Table 3. Panel Regression of Portfolio Allocation

\begin{tabular}{|c|c|c|c|c|c|c|}
\hline & \multicolumn{3}{|c|}{ Large Banks } & \multicolumn{3}{|c|}{ Small Banks } \\
\hline & Model 1 & Model 2 & Model 3 & Model 1 & Model 2 & Model 3 \\
\hline TAU & $\begin{array}{l}-0.012 \\
(-1.260)\end{array}$ & $\begin{array}{l}-0.012 \\
(-1.265)\end{array}$ & $\begin{array}{l}-0.011 \\
(-1.263)\end{array}$ & $\begin{array}{l}-0.083 * * * \\
(-4.652)\end{array}$ & $\begin{array}{l}-0.083 * * * \\
(-4.642)\end{array}$ & $\begin{array}{l}-0.083 * * * \\
(-4.643)\end{array}$ \\
\hline GAP1 & $\begin{array}{l}-0.549 \\
(-0.290)\end{array}$ & & & $\begin{array}{l}0.042 * * * \\
(3.859)\end{array}$ & & \\
\hline GAP2 & & $\begin{array}{l}2.083 * * \\
(2.167)\end{array}$ & & & $\begin{array}{l}0.098 \\
(1.585)\end{array}$ & \\
\hline GAP3 & & & $\begin{array}{l}-0.026 * * * \\
(-3.331)\end{array}$ & & & $\begin{array}{l}0.095 \\
(1.604)\end{array}$ \\
\hline LIQRAT & $\begin{array}{l}-0.221 * * \\
(-2.431)\end{array}$ & $\begin{array}{l}-0.247 * * \\
(-2.566)\end{array}$ & $\begin{array}{l}-0.265 * * * \\
(-3.186)\end{array}$ & $\begin{array}{l}-0.010 \\
(-0.427)\end{array}$ & $\begin{array}{l}-0.012 \\
(-0.506)\end{array}$ & $\begin{array}{l}-0.012 \\
(-0.483)\end{array}$ \\
\hline CAPRAT & $\begin{array}{l}0.315^{*} \\
(1.946)\end{array}$ & $\begin{array}{l}0.286^{*} \\
(1.691)\end{array}$ & $\begin{array}{l}0.278 \\
(1.636)\end{array}$ & $\begin{array}{l}0.029 * * * \\
(3.740)\end{array}$ & $\begin{array}{l}0.029 * * * \\
(3.649)\end{array}$ & $\begin{array}{l}0.029 * * * \\
(3.696)\end{array}$ \\
\hline ROA & $\begin{array}{l}-0.936 * * * \\
(-2.905)\end{array}$ & $\begin{array}{l}-0.717 * * \\
(-2.090)\end{array}$ & $\begin{array}{l}-0.724 * * \\
(-2.154)\end{array}$ & $\begin{array}{l}-1.399 * * * \\
(-9.767)\end{array}$ & $\begin{array}{l}-1.429 * * * \\
(-9.937)\end{array}$ & $\begin{array}{l}-1.439 * * * \\
(-10.012)\end{array}$ \\
\hline PTLL & $\begin{array}{l}0.284 \\
(1.085)\end{array}$ & $\begin{array}{l}0.625^{*} \\
(1.780)\end{array}$ & $\begin{array}{l}0.649 * * \\
(1.983)\end{array}$ & $\begin{array}{l}0.000 * * * \\
(6.230)\end{array}$ & $\begin{array}{l}0.000 * * * \\
(6.420)\end{array}$ & $\begin{array}{l}0.000 * * * \\
(6.486)\end{array}$ \\
\hline TA & $\begin{array}{l}0.075 * * * \\
(5.846)\end{array}$ & $\begin{array}{l}0.077 * * * \\
(6.062)\end{array}$ & $\begin{array}{l}0.078 * * * \\
(6.172)\end{array}$ & $\begin{array}{l}0.125 * * * \\
(23.844)\end{array}$ & $\begin{array}{l}0.124 * * * \\
(23.614)\end{array}$ & $\begin{array}{l}0.124 * * * \\
(23.599)\end{array}$ \\
\hline Bank Effects & Yes & Yes & Yes & Yes & Yes & Yes \\
\hline Obs & 28687 & 28534 & 28474 & 272757 & 272868 & 272932 \\
\hline R-squared & 0.032 & 0.036 & 0.034 & 0.042 & 0.041 & 0.041 \\
\hline
\end{tabular}

$* * * * *$, and * indicate $1 \%, 5 \%$, and $10 \%$ significance respectively

The coefficient of GAP1 is significant and consistent with the theory in small banks. On the other hand, the interest rate spread between time deposits and transactions deposits, represented by GAP2 and GAP3, is more evident in large banks. However, the negative coefficient of GAP3 is not coherent with the theory.

The result on liquidity buffer is more interesting. Just as the theoretical model suggests, the coefficient of the liquidation cost is positive in both large and small banks after the financial crisis, albeit significance only exists in the latter one. Reverse situation occurs in pre-crisis period and during the crisis, which implies that commercial banks did not raise the position of liquidity buffer in accordance with the increase of TAU. That could exacerbate the liquidity shortage amid the credit crunch. Small commercial banks have similar results despite massive wholesale funding withdrawals mostly occurred in core money center banks. In post-crisis period, the coefficient of liquidation cost is significantly positive.

In the post-crisis era, the general interest rate has been low, and the positive coefficient of GAP3 in large banks is consistent with the theoretical specification, especially in small banks. The significant coefficient also exists in large banks during the crisis suggests that the unobservable $\varphi$ might be a neutralizer even though the term structure is steep during the crisis.

Table 4. Panel Regression of Liquidity Buffer

\begin{tabular}{lllllll}
\hline \multirow{2}{*}{ TAU } & \multicolumn{3}{c}{ Large Banks } & & \multicolumn{3}{c}{ Small Banks } \\
& Pre-crisis & Crisis & Post-Crisis & Pre-crisis & Crisis & Post-Crisis \\
\cline { 2 - 6 } GAP3 & -0.000 & $-0.007 * * *$ & 0.003 & 0.002 & -0.000 & $0.004 * *$ \\
& $(-1.048)$ & $(-7.120)$ & $(0.99)$ & $(1.332)$ & $(-1.162)$ & $(2.255)$ \\
LIQRAT & $(1.565)$ & $2.591 * * *$ & $0.005 * * *$ & 1.420 & 0.242 & -0.000 \\
& $0.228 * * *$ & $(8.350)$ & $(7.266)$ & $(1.135)$ & $(1.486)$ & $(-0.005)$ \\
CAPRAT & $(3.736)$ & $(2.387)$ & $(23.191)$ & $(24.808)$ & $(10.028)$ & $(54.409)$ \\
& 0.049 & 0.064 & -0.014 & $-0.027 * * *$ & $-0.016 * *$ & $0.004 * * *$ \\
ROA & $(1.267)$ & $(0.857)$ & $(-0.660)$ & $(-5.892)$ & $(-2.092)$ & $(2.945)$ \\
& -0.071 & 0.133 & 0.100 & $0.109 * * *$ & 0.020 & $0.444 * * *$ \\
PTLL & $(-1.192)$ & $(1.317)$ & $(1.551)$ & $(5.821)$ & $(0.272)$ & $(10.693)$ \\
& -0.131 & $1.251 * * *$ & $0.197 * * *$ & $0.000 * * *$ & $0.552 * * *$ & $0.198 * * *$ \\
TA & $(-1.513)$ & $(4.980)$ & $(3.318)$ & $(-16.903)$ & $(7.682)$ & $(5.239)$ \\
& $-0.008 * * *$ & 0.005 & $-0.007 * * *$ & $-0.013 * * *$ & $0.017 * * *$ & $-0.003 * *$ \\
Bank Effects & $(-5.210)$ & $(0.776)$ & $(-3.379)$ & $(-18.82)$ & $(4.122)$ & $(-2.178)$ \\
Obs & Yes & Yes & Yes & Yes & Yes & Yes \\
R-squared & 0.198 & 3066 & 15660 & 124043 & 31383 & 117615 \\
\hline
\end{tabular}


***, **, and * indicate $1 \%, 5 \%$, and $10 \%$ significance respectively

\section{Concluding Remarks}

This study focuses on the portfolio allocation and liquidity buffer and how they are affected by the liquidation cost and risk preference. The biggest difference of this paper from previous literature is the employment of framing effect in the classic bank run model and the analysis of determinants of liquidity buffer that a bank should hold in the face of funding liquidity shock. Wholesale funding, which plays a key role in the recent financial crisis, is also incorporated in analysis of bank run conditions. This paper builds the connection between liquidity buffer and wholesale funding, and proposes a new perspective that the holding of liquidity buffer should be determined in line with wholesale liquidity needs. In the theoretical environment, I changed the typically assumed anticipation of depositors that late withdrawals will be paid less that early withdrawals.

The liquidation cost is negatively correlated with the investment ratio $i$, which is consistent with most previous literature. As the reference point moves rightwards, the investment ratio i will decrease, which implies that a more significant framing effect represented by a higher reference point negatively correlates with the portion of endowment allocated into long-term project. The relatively high proportion of illiquid assets shows the real decision-maker formulates an investment strategy without considering the stylized risk preference of lenders. In other words, the theoretical model of bank run with reference point indicates that the proportion of long-term assets should be restrained as a result of the increase of liquidation cost or the rightward move of the reference point. Empirical results are evident except GAP3 in large banks. The lower bound of liquidity buffer will be raised as the liquidation cost increases. This indicates that the ideal liquidity buffer positively correlates with the difficulty of market clearing of the long-term investment. The empirical results show that large commercial banks should have raised their holding of liquidity buffer in keeping with the upward trend of liquidation cost before the crisis. Since the banks failed to augment the position of liquid assets, the coefficient consequently displays negative significance during the crisis period. The negative coefficient of liquidation cost in the second regression implies that liquidity buffer in large banks is insufficient during the crisis period. The relationship between liquidity buffer and the reference point maintains negative regardless of how steep the term structure will be. The results are conducive to deepen the understanding of the natural fragility in the liquidity management of commercial banks.

One practical implication based on the results of this paper is the exploration and discussion of optimal liquidity buffer. It is clear that liquidity buffer could not be a constant variable which represents the absolutely optimal value of liquidity holding in commercial banks, while the liquidity buffer should be dynamic and adjustable under different economic circumstances. On the other hand, it is also necessary to study the framing effect of general depositors, especially institutional wholesale lenders, and incorporate the effect into the modeling of bank run and more extensive banking crisis. The reference point helps to explain the unobservable factors overlooked by the traditional analytical framework.

\section{Reference}

Acharya, V. V., \& Mora, N. (2015). A crisis of banks as liquidity providers. The Journal of Finance, 70(1), 1-43. https://doi.org/10.1111/jofi.12182

Acharya, V. V., Schnabl, P., \& Suarez, G. (2013). Securitization without risk transfer. Journal of Financial Economics, 107, 515-536. https://doi.org/10.1016/j.jfineco.2012.09.004

Allen, F., \& Gale, D. (1998). Optimal financial crises. The journal of finance, 53(4), 1245-1284. https://doi.org/10.1111/0022-1082.00052

Berger, A. N., \& Bouwman, C. H. (2009). Bank liquidity creation. The Review of Financial Studies, 22(9), 3779-3837. https://doi.org/10.1093/rfs/hhn104

Brunnermeier, M. K. (2009). Deciphering the liquidity and credit crunch 2007-2008. Journal of Economic Perspectives, 23, 77-100. https://doi.org/10.1257/jep.23.1.77

Brunnermeier, M. K., \& Pedersen, L. H. (2009). Market liquidity and funding liquidity. Review of Financial Studies, 22(6), 2201-2238. https://doi.org/10.1093/rfs/hhn098

Cooper, R., \& Ross, T. W. (1998). Bank runs: liquidity costs and investment distortions. Journal of Monetary Economics, 41(1), 27-38. https://doi.org/10.1016/S0304-3932(97)00070-6

Cornett, M. M., McNutt, J. J., Strahan, P. E., \& Tehranian, H. (2011). Liquidity risk management and credit supply in the financial crisis. Journal of Financial Economics, 101(2), 297-312. https://doi.org/10.1016/j.jfineco.2011.03.001

Diamond, D. W., \& Dybvig, P. H. (1983). Bank runs, deposit insurance, and liquidity. Journal of Political Economy, 91(3), 401-419. https://doi.org/10.1086/261155

Diamond, D. W., \& Rajan, R. G. (2001). Liquidity risk, liquidity creation and financial fragility: a theory of banking. 
Journal of Political Economy, 109, 287-327. https://doi.org/10.1086/319552

Ennis, H. M., \& Keister, T. (2009). Bank runs and institutions: the perils of intervention. American Economic Review, 99(4), 1588-1607. https://doi.org/10.1257/aer.99.4.1588

Ennis, H. M., \& Keister, T. (2009). Run equilibria in the Green-Lin model of financial intermediation. Journal of Economic Theory, 144(5), 1996-2020. https://doi.org/10.1016/j.jet.2009.05.001

Ennis, H. M., \& Keister, T. (2010). Banking panics and policy responses. Journal of Monetary Economics, 57(4), 404-419. https://doi.org/10.1016/j.jmoneco.2010.04.005

Goldstein, I., \& Pauzner, A. (2005). Demand-deposit contracts and the probability of bank runs. the Journal of Finance, 60(3), 1293-1327. https://doi.org/10.1111/j.1540-6261.2005.00762.x

Green, E. J., \& Lin, P. (2003). Implementing efficient allocations in a model of financial intermediation. Journal of Economic Theory, 109(1), 1-23. https://doi.org/10.1016/S0022-0531(02)00017-0

Holmström, B., \& Tirole, J. (1997). Financial intermediation, loanable funds, and the real sector. Quarterly Journal of Economics, 112(1), 35-52. https://doi.org/10.1162/003355397555316

Kahneman, D., \& Tversky, A. (1979). Prospect theory: an analysis of decision under risk. Econometrica, Journal of the Econometric Society, 263-291. https://doi.org/10.2307/1914185

Kashyap, A. K., Rajan, R., \& Stein, J. C. (2002). Banks as liquidity providers: an explanation for the coexistence of lending and deposit-taking. Journal of Finance, 57, 33-73. https://doi.org/10.1111/1540-6261.00415

Loutskina, E. (2011). The role of securitization in bank liquidity and funding management. Journal of Financial Economics, 100(3), 663-684. https://doi.org/10.1016/j.jfineco.2011.02.005

Morris, S., \& Shin, H. S. (2004). Liquidity black holes. Review of Finance, 8(1), 1-18. https://doi.org/10.1023/B:EUFI.0000022155.98681.25

Tversky, A., \& Kahneman, D. (1992). Advances in prospect theory: cumulative representation of uncertainty. Journal of Risk and Uncertainty, 5(4), 297-323. https://doi.org/10.1007/BF00122574

Uhlig, H. (2010). A model of a systemic bank run. Journal of Monetary Economics, 57(1), 78-96. https://doi.org/10.1016/j.jmoneco.2009.10.010

\section{Note:}

Note 1: MBS issued by U.S. government agencies or by U.S. government-sponsored enterprises such as the GNMA, FNMA and FHLMC.

Note 2: Pass-through securities not guaranteed by the U.S. government and other MBS issued by non-U.S. government issuers and those collateralized by MBS issued or guaranteed by FNMA, FHLMC, or GNMA.

Note 3: The variable TA is the logarithm of the raw data.

\section{Copyrights}

Copyright for this article is retained by the author(s), with first publication rights granted to the journal.

This is an open-access article distributed under the terms and conditions of the Creative Commons Attribution license which permits unrestricted use, distribution, and reproduction in any medium, provided the original work is properly cited. 